\title{
Technè
}

La science au service de l'histoire de l'art et de la préservation des biens culturels

$44 \mid 2016$

Archives de l'humanité : les restes humains patrimonialisés

\section{The Egyptian mummy in UK museums: cultural histories and object biographies}

Les momies égyptiennes dans les musées anglais : histoire culturelle et "biographie d'objets "

\section{Angela Stienne}

\section{OpenEdition}

\section{Journals}

\section{Electronic version}

URL: http://journals.openedition.org/techne/993

DOI: 10.4000/techne.993

ISSN: 2534-5168

\section{Publisher}

C2RMF

\section{Printed version}

Date of publication: 1 November 2016

Number of pages: 40-44

ISBN: 978-2-7118-6339-6

ISSN: $1254-7867$

\section{Electronic reference}

Angela Stienne, "The Egyptian mummy in UK museums: cultural histories and object biographies », Technè [Online], 44 | 2016, Online since 19 December 2019, connection on 23 July 2020. URL : http:// journals.openedition.org/techne/993; DOI : https://doi.org/10.4000/techne.993

\section{(c) $($ ) $\odot$ (PY}

La revue Technè. La science au service de l'histoire de l'art et de la préservation des biens culturels est mise à disposition selon les termes de la Licence Creative Commons Attribution - Pas d'Utilisation Commerciale - Pas de Modification 4.0 International. 


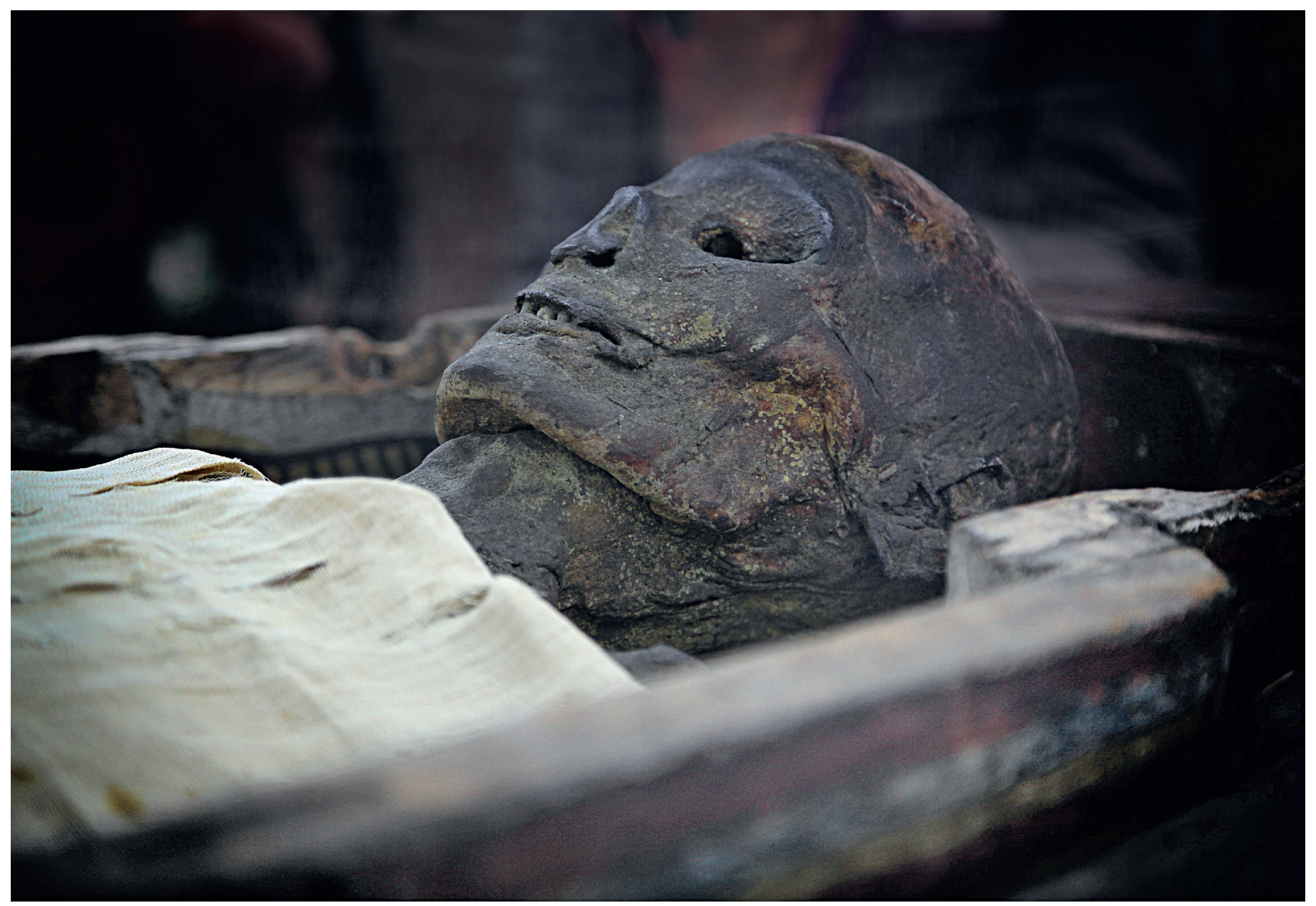

Fig. 1. The mummy of Asru at the Manchester Museum.

(c) Courtesy of Manchester Museum, The University of Manchester. 
Angela Stienne The Egyptian mummy in UK museums:
cultural histories and object biographies

Les momies égyptiennes dans les musées anglais : histoire culturelle et «biographie d'objets »

Abstract. Egyptian mummies are at the centre of attention of most Egyptology collections. Their dual nature as bodies (human remains) and artefacts make them peculiar museum objects and, consequently, they have been left out of the debate concerning the collection, retention and display of human remains. This paper aims to reinvigorate the debate over the display of Egyptian mummies in museums by addressing three points: the 'object habits' of collectors which led to the building up of mummy collections, the specificity of mummies and how it has been addressed by $U K$ museum authorities, and finally, the new modes of display, making a case for a better understanding of human remains collections through the use of object biographies.

Keywords. Human remains, museum collections, Egyptian mummies, object biography, cultural history.
Résumé. Les momies occupent une place centrale dans la plupart des collections d'égyptologie. Leur double nature de corps (restes humains) et d'œuvres en fait des objets à part, laissés à l'écart $d u$ débat sur la collection, la détention et l'exposition de restes humains. Cet article relance la réflexion sur l'exposition des momies égyptiennes dans les musées autour de trois thèmes: le rapport à l'objet qui a conduit à constituer des collections de momies, la spécificité des momies et sa prise en compte par les instances muséales anglaises et, enfin, les nouveaux modes de présentation. Les biographies d'objets contribuent à une meilleure appréhension des collections de restes humains.

Mots-clés. Restes humains, collections de musées, momies égyptiennes, biographie d'objets, histoire culturelle.
At the turn of the $21^{\text {st }}$ century, the collection, retention and display of human remains in museums have become matters of serious contention. Human remains have generated emotionally-charged reactions and been the subject of sensitive repatriation claims. These lead to the question: how and why did these artefacts enter museum collections and do they still have a role in contemporary museum practice? Numerous publications in the United Kingdom have appeared addressing precisely these issues ${ }^{1}$.

However, there is as yet little consensus amongst historians, contemporary practitioners and institutions as to the appropriate response to these concerns. The place of Egyptian mummies in museums, for example, has never been systematically examined, and more often than not, the public understanding of Egyptian mummies remains connected to images from popular culture. As Dr John Taylor, Assistant Keeper in charge of funerary collections at the British Museum's Department of Egypt and the Sudan has pointed out, "while they have had a major impact on the public perception about Ancient Egypt, the mummies as a whole have not been consistently studied ${ }^{2}$."

An examination of the cultural histories and object biographies of Egyptian human remains raises the questions: how is the identity of the Egyptian mummy framed in the museum space, and what are the variables involved in changing attitudes towards these objects? Examining permanent and temporary displays in the UK, this paper seeks to open up a debate concerning the study and display of Egyptian human remains.

\section{Museum artefacts and medical corpses: the collecting of mummies}

The extensive and diverse history of the mummy's entry into European culture and its subsequent admission into scientific Egyptology has meant that many of the reasons mummies were collected have been lost or forgotten. The cultural histories behind the building up of private and public collections of Egyptian human remains, which have been dismissed as accidental and with little incidence on both the reception of the mummy and the display of Egyptian human remains, illustrate how the identity of Egyptian mummies was constantly evolving as the mummy entered different contexts. The British Museum's mummy collection, the largest outside of Egypt, was begun by its founding donor, Sir Hans Sloane (1660-1753), who collected at least three Egyptian mummies. It was, however, the donation of another collector, Colonel Lethieullier, a former member of the short-lived Egyptian Society in 
London, which attracted public attention on the opening of the museum on 15 January 1759 . Thus, the origin of the British Museum collections lies in contemporary sociocultural practices that predate the museum. On entering the museum, however, with greater exposure to the public and evolving institutional practices, the mummy was bound to change. A further change would take place a century later when most other human remains were moved to the new British Museum (Natural History), ensuring that the Egyptian mummies at the British Museum would be perceived as archaeological, rather than biological, remains.

This biological aspect was developed to a high degree in the eighteenth century when the identity of the mummy as a corpse was fostered by authoritative figures in the medical sciences. The first published account of a dissection of an Egyptian mummy by John Hadley (1731-1764) was based on a procedure conducted by John Hunter (1728-1793) at the Royal Society of London in $1763^{3}$. The mummy's foot from this dissection survives at the Hunterian Museum at the Royal College of Surgeons in London. Less than thirty years later, in 1791, it was questions of race and human origins that encouraged Johann Friedrich Blumenbach (1752-1840) to dissect mummies. The mummy's identity was changing according to society's questions not simply about Egypt but about itself and its culture. Later, highly theatrical unrolling sessions staged by Giovanni Battista Belzoni (1778-1823), Augustus Bozzi Granville (1783-1872) and Thomas Joseph Pettigrew (17911865 ) would again reposition the mummy in society as an object of mystery and performance. Denigrated as evidence of mummymania, these rich cultural contexts have often been omitted from histories of eighteenth and nineteenth century engagement with Egyptian mummies. However, it is evident that the practice of revealing bodies through dissection and unwrapping contributed directly to contemporary understandings of Ancient Egypt ${ }^{4}$.

\section{Displaying human remains in UK museums: the specificity of the mummy}

While the presence of the dead body in museums in the UK has led to debate, it has been the controversy surrounding the holding of indigenous remains from other parts of the world that has forced a change of attitude. The active contribution of human remains in the understanding of past cultures is undeniable: human remains offer a lens through which researchers can contribute to the advancement of the archaeological understanding of the past, as well as contemporary concerns such as the development of diseases and climate change. Such research, however, no longer goes unchallenged by groups concerned with their identities, their cultural and religious beliefs, and the possession of their ancestors. By the end of the twentieth century, museums faced a major dilemma: could human remains be displayed in museums?

The debate surrounding human remains was captured in Giesen's publication, Curating Human Remains, Caring for the dead in the United Kingdom (2013), which addressed the ethical and practical issues faced by museums. On the matter of display, Woodhead stated that, "regardless of age, display must be mindful of the legal requirement that they must not outrage public decency", with 'outrage' being defined as something "disgusting and offensive" to the public, variables that are subjective and dependent on cultural background and personal feelings. Woodhead pointed out that skeletons from archaeological excavations as well as mummies are "unlikely to outrage public decency", a statement that demonstrates that mummies are nowadays distinguished from other more recent or sensitive categories of human remains ${ }^{5}$. The Department for Culture, Media and Sport's (DCMS) Guidance for the Care of Human Remains in Museums provides advice on the reasons and circumstances for public exhibitions, while the International Council of Museums' (ICOM) Code of Ethics '4.3 Exhibition of Sensitive Material' suggests that human remains should be "presented with great tact and respect for the feelings of human dignity ${ }^{6}$." The Museum Association's own Code of Ethics (2015) observes the sensitivity of visitors and advises on sign-posting human remains displays ${ }^{7}$.

Despite these attempts to provide a secure professional position on working with human remains, much depends upon the professionalism and sensitivity of staff. However, of particular interest here are the implications for Egyptian mummies which, while they are clearly not being amongst the most politically sensitive of human remains, nevertheless risk being drawn into the same ethical debate. This distinction, which has received little attention, can be verified by visitor studies that have concluded that displays of mummies in the UK are generally accepted, if not expected, by the visiting public ${ }^{8}$. As a result, few museums have re-examined their holding of mummy collections. The Manchester Museum initiated a review of its display of Egyptian mummies in 2008. A modified display was conceived with the prospect of redefining the idea of respect, not only toward the visitor, but also toward the deceased. The first stage consisted in covering up entirely the body of the mummy of Asru, which the visiting public found absurd (fig. 1). The second stage was the reopening of the gallery in 2012, with only one mummy out of eight on display, placed in a partially obscured case with the intention to make the mummy visible only to those who approach the body very closely.

\section{The future of mummy display: a case for object biographies}

Object biographies are a means through which the cultural histories of Egyptian mummies and museum displays can coalesce around the shared aim of presenting the mummy as the embodiment of its different identities: archaeological artefact, corpse, pathologist's specimen, and also, image of a mythical figure. 
The DCMS Guidance states that human remains should be displayed with "sufficient explanatory material", but what makes a display sufficiently explanatory and through which means ${ }^{9}$ ? Montserrat in Ancient Egypt: Digging for Dreams (2000), noted that "the Egyptians placed such emphasis on maintaining the offering cult and speaking the names of the dead that they might have been horrified by museum displays of anonymous mummies ${ }^{10}$." The ancient Egyptians believed in the necessity of maintaining the corpse in a good state in order for the deceased to travel between the human world and the afterlife. The saying of the name was a fundamental part of a highly codified set of practices that were necessary in keeping the essence of life for the deceased. However, to this day, names are often omitted in museum displays around the world even when this information is known. The body is simply referred to as a 'mummy', a word which comes from the Persian for bitumen in reference to the black substance covering some mummies, which does not describe the nature of the displayed subject. In Britain, museums are increasingly using names and life biographies in displays. Oxford's Ashmolean Museum even went as far as to translate the mortuary inscription on one mummy's coffin. The 2000 exhibition Digging for Dreams curated by University of London's Petrie Museum of Egyptian Archaeology combined educational engagement with the idea of respecting the dead person's mortuary beliefs. This was achieved by protecting the mummy with a linen shroud, but inviting visitors to uncover the display while reciting respectful formulas translated from ancient Egyptian funerary texts (fig. 2 and 3 ). This transcended the simple observation of a body as it forced the viewer to engage in an act that acknowledged the person.

In recent years, the development of bioarchaeology and forensic archaeology has led to an ever-evolving understanding of conditions of life and death of the Egyptian bodies in museum collections. The data collected have been gradually included in museum exhibitions, for example, through videos explaining the Mummy Tissue Bank at the Manchester Museum. The potential of X-rays was realised in the $1890 \mathrm{~s}$ although the solidified resins used in the mummification process impaired the clarity of images. The issue was addressed by the development of computerised axial tomography. CTscans are used as a metaphor for transparency in museum displays, allowing the visitor to uncover data on the bodies they are encountering. The 2014 Ancient Lives, New Discoveries exhibition at the British Museum offered the visitor the opportunity to virtually unwrap Egyptian mummies through the use of enhanced digital technology.

The implementation of new display strategies which encourage interaction between visitors and human remains poses countless issues: are we really revealing the human nature of mummified bodies - with all its meanings - by encouraging individuals to play with virtual body parts? And, are museums really tapping into the narrative potential of Egyptian mummies? As Joy pointed out, "the biography of
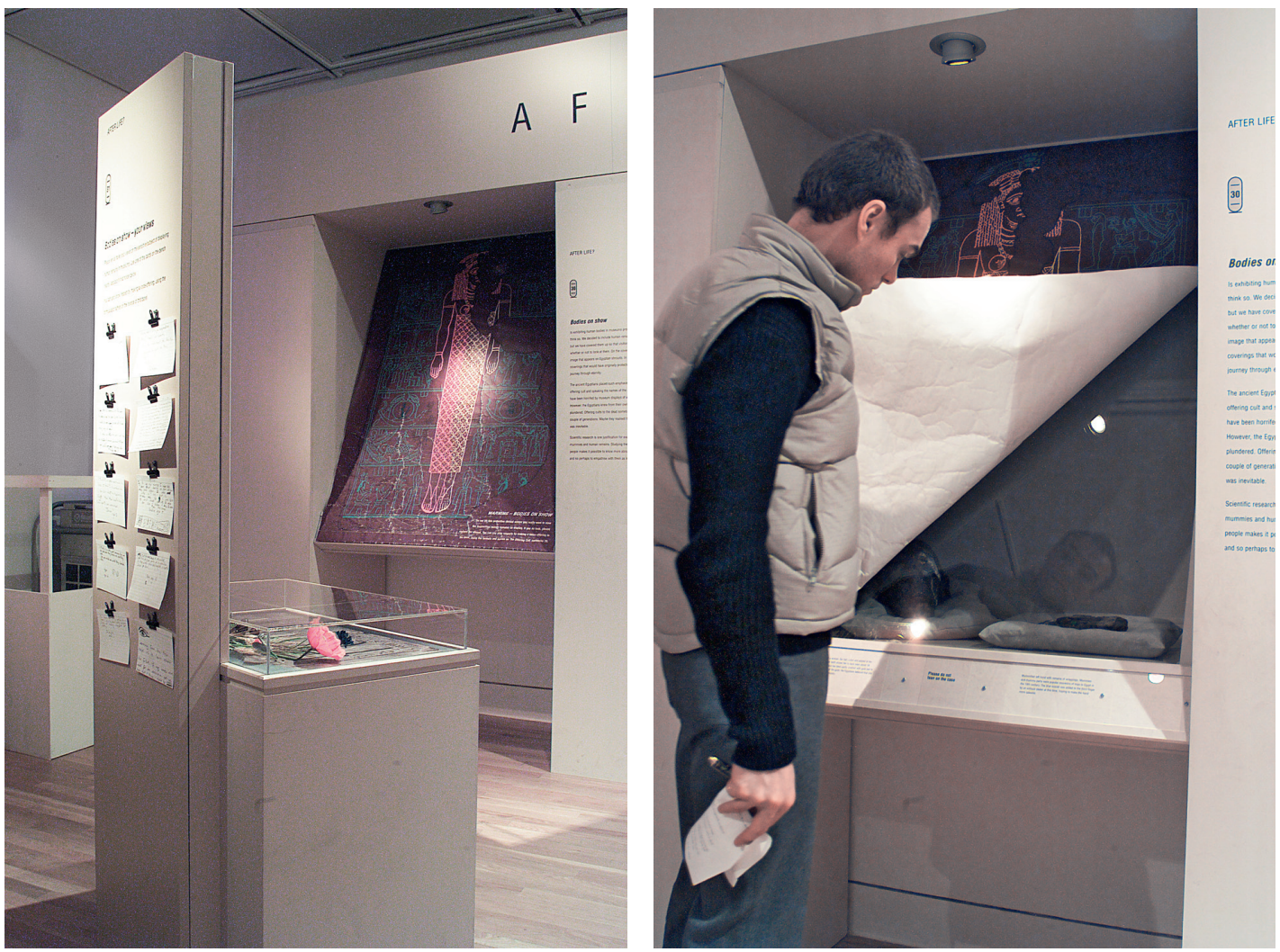

Fig. 2 and 3. Digging for Dreams at the Petrie Museum: display covered with a linen shroud, which is then lifted by a visitor. @ Courtesy of the Petrie Museum of Egyptian Archaeology, UCL. 
an object should not be restricted to an historical reconstruction of its birth, life and death. Biography is relational and an object biography is comprised of the sum of the relationship that constitute it ${ }^{11}$." Displays have the potential to include object biographies that go beyond the scientific data of the dead body's lifetime: upon being excavated, Egyptian mummies have entered a new lifeline, and these stories are rarely included in museum displays. Recent works in the United Kingdom have opted for a multidisciplinary approach using methodologies based in archaeology, history, museum studies and anthropology to produce fundamental research on the relationship between acquisition, museum display and public reception: Moser's Wondrous curiosities (2006), Rigg's Unwrapping Ancient Egypt (2013) and the University College

\section{Conclusion}

The Museum Association's advice on 'Displaying human remains' states: "Displaying human remains can help people to learn about, understand and reflect upon different cultures and periods of history. They can also cause distress to certain individuals or groups. Display them only if the museum believes that they make a material contribution to a particular interpretation ${ }^{12}$." Egyptian mummies are a familiar and less controversial category of human remains but their human nature nevertheless places them in the same framework of ethical issues. It seems nonetheless that the $21^{\text {st }}$ century museum should seek solutions that do not result in the removal of Egyptian mummies from display, as suggested by the Museum Association. This paper suggests that the solution can be obtained through a rich understanding of these objects as cultural objects and human remains. Displays need to observe this complexity and pay respect not just through careful design and visitor performance, but through the provision of new information about the history of our relationship to these objects.

\section{Notes}

1. Fletcher et al., 2014; Were and King, 2012; Giesen, 2013.

2. Taylor, 2014, p. 103.

3. Hadley, 1764, p. 1-14.

4. Riggs, 2014

5. Woodhead, 2013, p. 35.

6. DCMS, 2005, p. 20; ICOM, 2013, p. 8.

7. Museum Association, 2015, 2.(c).

8. Kilmister, 2003, p. 57-69.

9. DCMS, 2005, p. 20.

10. Montserrat, 2000, p. 26.

11. Joy, 2009, p. 552.

12. Museum Association, 2015, 2.(c).

\section{Bibliographie}

Brooks M. M., Rumsey C., 2007, “'Who knows the fate of his bones?' Rethinking the body on display: object, art or human remains?", in Knell S., MacLeod S., Watson S., Museum Revolutions, how museums change and are changed, Routledge, Oxon.

Carruthers W., 2013, Histories of Egyptology: Interdisciplinary Measures, Routledge, London.

Day J., 2006, The Mummy's Curse, Mummymania in the English Speaking World, Routledge, Oxon.
Department for Culture, Media and Sport, 2005, Guidance for the Care of Human Remains in Museums [En ligne], consulté le 6 février 2016. URL: http:// webarchive.nationalarchives.gov.uk/+/ http://www.culture.gov.uk/reference_ library/publications/3720.aspx

Fletcher A., Antoine D., Hill J. D., 2014, Regarding the Dead: Human Remains in the British Museum, The Trustees of the British Museum, London.

Giesen M., 2013, Curating Human Remains, Caring for the Dead in the United Kingdom, The Boydell Press, Woodridge.

Hadley J., 1764, "An account of a mummy, inspected at London 1763", Philosophical Transactions of the Royal Society, p.1-14.

International Council of Museums, 2013, ICOM Code of Ethics for Museums [En ligne], consulté le 6 février 2016. URL: http://icom.museum/fileadmin/user_ upload/pdf/Codes/code_ethics2013_ eng.pdf

Joy J., 2009, "Reinvigorating object biography: reproducing the drama of object lives", World Archaeology, 41: 4, p. 540-556.

Kilmister H., 2003, "Visitor Perceptions of Ancient Egyptian Human Remains in Three United Kingdom Museums", Papers from the Institute of Archaeology 14, p. 57-69.

Lohman J., Goodnow K., 2007, Human Remains and Museum Practice, UNESCO and the Museum of London, Paris and London.

Moser S., 2006, Wondrous Curiosities, Ancient Egypt at the British Museum, The University of Chicago Press, Chicago.

Montserrat D., 2000, Ancient Egypt, Digging for Dreams, Glasgow City Council, Cultural \& Leisure Services, Glasgow.

Museum Association, 2015, Code of Ethics: Additional Guidance [En ligne], consulté le 6 février 2016. URL:

http://www.museumsassociation.org/ download? id $=1155817$

Riggs C., 2014, Unwrapping Ancient Egypt, Bloomsbury Academic, London.

Taylor J. H., 2014, "The Collection of Egyptian Mummies in the British Museum: Overview and Potential for Study", in Fletcher A., Antoine D., Hill J. D., Regarding the Dead: Human Remains in the British Museum, The Trustees of the British Museum, London, p. 103-114.

Were G., King J. C. H., 2012, Extreme Collecting, Challenging Practices for $21^{\text {st }}$ Century Museums, Berghahn Books, London.

Woodhead C., 2013, "Care, Custody and Display of Human Remains: Legal and Ethical Obligations", in Giesen M., Curating Human Remains, Caring for the Dead in the United Kingdom, The Boydell Press, Woodridge, p. 31-41. 